USA until Canadian officials are available to conduct the first screening hearing. The scale is large - an estimated $500-1000$ persons refouled per month. At these major border points the wait in the USA is at least a month. (Of course this refoulement to the USA discriminates against persons coming via the USA. Also, denying rights on the grounds of administrative convenience is counter to the Supreme Court of Canada decision on Singh et al.)

A new backlog or 'frontlog' is accumulating. Testimony before the 1987 Senate Hearings on the then proposed new law revealed that backlogs occurred in the part of the procedure controlled by the Immigration Department leading up to the first inquiry. At that time the churches argued that the new law did not deal with this problem because it retained the inquiry, now the screening hearing, controlled by the Immigration Department and presided over by an Immigration Adjudicator. The government statistics reveal that this is once again the case. The 'frontlog' now stands at over 17,000 cases and the average delay before the screening is reported as seven months. As of October 31,1990 , of the over 50,000 arrivals, only some 10,000 cases have been heard to completion and only about 7,000 refugees confirmed. It is hard to see this as success.

The Immigration statistics also show that $\mathbf{8 5 0}$ deportations have taken place. Voluntary sector groups have identified over 100 cases where serious mistakes in screening hearing or full hearing have occurred. These cases have been documented carefully. The inadequate "leave" for judicial review did nothing because it could not deal with the substance of a decision. Refugee serving groups report the lack of meaningful appeal as another major problem. It is true that this Minister has been persuaded to allow almost all of these cases to remain. However, not even those found and determined by voluntary groups to be refugees could be protected.

Continued on page 16

\title{
CANADIAN COUNCIL FOR REFUGEES RESOLUTIONS NOVEMBER, 1990 (EDITED)
}

\section{BE IT RESOLVED THAT THE CCR : Family Reunification:}

1. demand the Minister of Employment and Immigration end the separation of families immediately by taking steps to reunite them in Canada;

2. demand the Canadian government act on its promise and implement and publish specific effective procedures to reunite children and 'familial' caregivers immediately regardless of the caregiver's status in Canada;

\section{Refugee Claimants:}

3. request the Government of Canada to end the practice of sending refugee claimants back to the U.S. prior to the hearing of their refugee claims;

4. denounce in very clear language subjecting refugee claimants who may have experienced torture to hours of intense, hostile questioning by the Canadian Security and Intelligence Service, to the Prime Minister of Canada, the Solicitor-General of Canada and the Minister of Immigration and seek a response toensure an end to such practices and that the Human Rights Commission be made aware of such practices;

\section{Backlog:}

5. demand that the Minister keep her promise that cases in the Backlog be dealt with on a first come, first served basis, and cease the discriminatory practice of expediting cases believed to be manifestly unfounded;

6. communicate dissatisfaction to the Minister with the practice of denying landing for claimants in the backlog (for reasons related to their inability to support themselves financially and obliging such persons, many of whom are single mothers, elderly or with medical handicaps, to attend a full refugee hearing) and demand that the practice be stopped;

7. endorse and support through its members and executive the ICCR brief, "Civil Rights and the Refugee Claimant Backlog" recently submitted to the UN Human Rights Committee by letters to the Ministers of EIC, External Affairs and the Justice Department;
8. consider seeking funding to mount an individual legal challenge based on the principles of the delay of justice and the cruel and inhuman treatment inflicted, in violation of the UN covenants and the Canadian charter;

Iranians:

9. write to the Minister requesting that she instruct her officials to stop forcing Iranians to make application to the Iranian consulate for travel documents;

Sri Lankans:

10. call upon the Minister of Employment and Immigration

- immediately to impose a moratorium on the removal of Sri Lankans from Canada;

- permit Sri Lankan nationals in Canada subject to removal orders to apply for permanent residence;

and urge all CCR members to communicate this request to the Minister on their own behalf;

People's Republic of China:

11. request that the Minister of Employmentand Immigration administer the program for nationals from the People's Republic of China (PRC) consistently and fairly;

implement the expectation that candidates would generally be accepted on humanitarian grounds (and not forced to make refugee claims);

allow their families in the meantime to come to Canada on Minister's Permits;

extend work authorizations;

Lebanese:

12. ask the Minister of Immigration to extend the moratorium on the removal of Lebanese from Canada;

Funding:

13. requests an immediate change in the ISAP eligibility criteria to include services to refugee claimants;

and that

the ISAP budget be increased to represent a minimum of $10 \%$ of the Federal Immigration Budget;

and that

the Executive of the CCR communicate this message immediately to the Minister. 
14. communicate with the federal and provincial governments requesting them to establish an efficient funding mechanism that will result in greatly increased funding for the centres working with survivors of torture, and in the provision of funding for services where none are currently available;

request Health and Welfare Canada to evaluate the resources necessary to meet the needs of the survivors as outlined in the report "After the Door is Opened" and to consult groups working with refugees, including settlement agencies in the process, these resources to be available to all survivors immediately on arrival in Canada, regardless of immigration status;

strongly urge the federal government to provide training on the subject of the phenomenon of torture and its sequelae for Immigration officers, members of the Immigration and Refugee Board, Refugee Hearing Officers and adjudicators;

strongly urge that such training be made available to all lawyers dealing with refugees and made obligatory for all designated counsel;

strongly urge that full credence be given to professional evaluations of survivors of torture, including recommendations that questioning regarding the episode(s) of torture may result in retraumatization by those working within the refugee system, including the backlog process;

\section{Appointments to the Refugee Board:}

15. write to the Minister of justice and the Law Reform Commission and recommend the forming of a task force in consultation with the Canadian Bar association and the CCR and other interested parties to implement a fair and non-political appointment process for the CRDD (because of complaints of insensitivity, lack of an open system to evaluate competency or a procedure to receive complaints, and questionable qualifications of some of the appointees);

express support for the Ratushny report and agreement with its recommendations (to prefer qualifications and experience over political patronage; provision of guarantees of independence in relation to tenure, renumeration and immunity and protection from direct government interference; etc.);

\section{On Sponsorship:}

(Currently, there is a review underway on private sponsorship of refugees. The editor was elected Chair of the Steering Committee which is made up $50 \%$ of government civil servants and $50 \%$ from the NGO sector.)

\section{WITH RESPECT TO SUBSTANCE:}

16. direct that the following established principles be continuously articulated and upheld throughout the review process

as CCR positions (the first two were stated as fundamental non-negotiable elements of private sponsorship):

a) the naming of refugees in private sponsorship applications;

b) the need for the government to process all private sponsorship applications as swiftly as possible, with no ceiling restrictions;

c) maintaining the ability of private sponsorship to increase the number of refugees brought to Canada over and above the basic government quota as an important and highly valued component of Canadian immigration policy;

d) private sponsorship is complementary and must never replace a generous government sponsorship program;

e) selection of refugees for whom private sponsorship applications have been submitted should be accepted;

f) NHQ must ensure an accessible, speedy and credible review process for sponsorship refusals;

g) Master agreement holders and other sponsoring groups should not solicit or accept government funds for the administration of the private sponsorship program;

h) Private sponsorship applications must begiven priority at the posts abroad and this must include swift processing and regular communication with the sponsor including implementing procedures to prevent unreasonable delays;

i) There must be a common agreement and a globally consistent application of assessment criteria; j) Privately sponsored refugees must have equal access to any government provided settlement process;

\section{WITH RESPECT TO PROCESS}

17 (a) extend a formal invitation to the Steering Committee to have the private sponsorship review national consultation take place in the context of the Spring consultation;

b) communicate with the membership on a regular basis on the progress of the private sponsorship review process;

c) present an examination and critique of the preliminary findings at the consultation and that there be an examination of and openness to a variety of models for private sponsorship;

d) plan jointly the agenda process and appropriate working papers for the consultation;

e) request that whatever funds the private sponsorship process has available for consultation be used to facilitate the participation of groups and persons who would be unable to attend the CCR meeting under normal circumstances (e.g., Master Agreement holders not members of $C C R$, persons who have participated in the review process)

18. recommend to the Steering Committee of the review project that the UNHCR be invited to participate in the review project;

\section{SOME RESOLUTIONS WERE \\ DIRECTED TO THE UNHCR}

19. urge UNHCR to consistently promote the view that it is unsafe to forcibly return Sri Lankans to Sri Lanka at the present time, and urge partner organizations in Europe, the Pacific and the USA to adopt and promote a similar position;

20. invite the UNHCR to all future consultations and introduce into the program of each meeting a consultation with the UNHCR;

21. ask the UNHCR to maintain the positions of legal officers across Canada and to realize its required funding cut by other means. B 